\title{
The editor's health: corrigendum and update
}

My family insists I should never try to tell jokes because I always seem to forget the punch line or otherwise mess it up. In the September issue I told the tale of my fractured heel. It should have ended with the clever pun 'Time wounds all heels' but my careless proofreading resulted in the not so funny, perhaps mysterious, 'Time wounds all heals'. Read it again with the correct spelling and I hope you will at least chuckle.

Anyway, I trust readers will be reassured that since my last update I have experienced no further injuries. It is, however, striking, that most of my friends and casual acquaintances immediately assumed that because I now occasionally wear a cervical collar I have somehow injured myself. ( $\mathrm{I}$ am certain there is a message in what assumption; I just haven't figured out that it is.) The collar is worn because of arthritis, brought on by wear and tear, also known as 'old age'. Could it be the result of having stuck my neck out too often over too many years?

\section{Children of the road}

A small change in car policy could bring great new freedoms

When a black and white photograph of a 1950s street scene is juxtaposed with the same street now, the most striking difference is the absence of the motor car. Then the streets were alsmost always filled with children playing. Now the road belongs to the car. Even the pavements have been lost to children. A conference held by the National Children's Bureau yesterday sought ways to redress that balance.

The Automobile Association called for the Government to experiment with a $10 \mathrm{mph}$ speed limit on some residential streets to see whether the threat of road accidents could be reduced. Steven Norris, the Transport Minister, seemed ready to take up the challenge: 'Certainly, if $20 \mathrm{mph}$ can be made to work I would not be averse to looking and seeing whether lower speeds still will work', he told the Play in the Streets conference.

Road traffic has nearly doubled over the past two decades and is forecast to double again by the time that today's children are parents themselves. The British accident rate for child pedestrians is 31 per cent higher than the EU average. Yet the child death rate has fallen hugely since the car was first introduced to Britain. In 1922, twice as many children were killed on the roads than now, even though there were 25 times fewer cars. This does not, however, suggest that streets have become safer. Rather, children have been withdrawn by their parents from the threat of traffic.

The threat of abduction, or 'stranger danger', exists more in the minds of parents than in reality. There will always be the occasional tragic and widely reported case of children being abducted or murdered by perverts. But the chances of this happening are minuscule; which is why when it does, it receives such extensive media coverage.

Traffic is another matter. It has hugely circumscribed children's freedom and independence. Children are no longer allowed to roam their neighbourhoods, to visit friends, to discover a world of the imagination that can be acted out free from adult supervision. Their ability to deal confidently with the outside world is much diminished. Their health suffers too; not just because the extra exhaust pollution can trigger asthma attacks, but because being ferried around in a car instead of walking or cycling has made today's children probably the least fit generation ever.

Transport planners must start to recognise that the rights of motorists to reach their destination as quickly as possible should not have domain over 100 per cent of Britain's roads. Other users have a stake too, not least children, who do not wield a vote. Their lives and the lives of their parents would be much improved if local authorities were to design safe routes to schools so that children could walk or cycle unaccompanied, and to enforce very low speed limits in selected residential areas. A small change in policy could lead to an enormous boost to children's freedom.

Reproduced with permission from The Times 21 November 1995 (C) Times Newspapers Ltd. 